\title{
Extracellular peroxidase activity in an experimentally divided lake (Große Fuchskuhle, northern Germany)
}

\author{
Ulrike Buck $^{1,3, *}$, Hans-Dietrich Babenzien ${ }^{1}$, Elke Zwirnmann ${ }^{2}$ \\ ${ }^{1}$ Leibniz-Institute of Freshwater Ecology and Inland Fisheries, Department of Limnology of Stratified Lakes, \\ Alte Fischerhuette 2, 16775 Stechlin, Germany \\ ${ }^{2}$ Central Chemical Laboratory, Mueggelseedamm 310, 12587 Berlin, Germany \\ ${ }^{3}$ Present address: Max Planck Institute of Marine Microbiology, Department of Molecular Ecology, Celsiusstr. 1, \\ 28359 Bremen, Germany
}

\begin{abstract}
Extracellular peroxidases act on aromatic compounds such as humic substances resulting in the formation of unstable radicals. Most organisms that are known to produce extracellular peroxidases are terrestrial, e.g. the wood-rotting fungus Phanerochaete chrysosporium and the Actinobacterium Streptomyces viridosporus. Only few studies focus on the action of these enzymes in the aquatic environment. In this study, the activities of extracellular peroxidases in 2 distinct compartments of the experimentally divided Lake Große Fuchskuhle, Germany (an acidic humic rich compartment and an almost neutral eutrophic compartment) and in the catchment area were investigated. Additionally, the effects of $\mathrm{pH}$ on extracellular peroxidase activity and of the size fractions of water samples associated with extracellular peroxidase activity were determined. Enzyme activity and the characterisation of the enzymes were assayed by oxididation of 2,2'-azino-di-(3-ethylbenzthiazoline-6-sulphonic acid) (ABTS). In the humic rich compartment, extracellular peroxidase activity was (except for 1 month) significantly higher than in the eutrophic compartment, with highest activities during fall and winter. In contrast, no peroxidase activity was detected in the catchment area. The $\mathrm{pH}$ optimum of extracellular peroxidases was $\mathrm{pH} 3$, and highest activity was detected in the $10 \mathrm{kDa}-0.2 \mu \mathrm{m}$ molecular weight class. Thus we documented the occurrence of extracelluar peroxidases in Lake Große Fuchskuhle and suggest that these enzymes are involved in the degradation of aromatic compounds such as humic substances.
\end{abstract}

KEY WORDS: Extracellular peroxidase · Exoenzymes $\cdot$ ABTS $\cdot$ Humic substances $\cdot$ Catchment area

\section{INTRODUCTION}

Extracellular peroxidases are enzymes that are mainly produced by micro-organisms such as basidiomycetous white-rot fungi and related litterdecomposing fungi, and also by Actinobacteria and plants (Tuomela et al. 2000). The best studied extracellular enzymes of white-rot fungi are lignin peroxidases, manganese peroxidases and laccases. In addition to these enzymes other extracellular peroxidases are known that are comparable to horseradish peroxidase in structure and reactivity (Petersen et al. 1993).
In the presence of hydrogen peroxide, these proteins act on aromatic compounds such as humic substances, resulting in the formation of unstable radicals. These radicals participate in chemical reactions leading to bond cleavage and thus degradation of aromatic compounds. Most known extracellular peroxidase-producing organisms have been isolated from terrestrial habitats (Tuomela et al. 2000, Hatakka 2001); few studies focus on extracellular peroxidase-producing organisms in the aquatic environment (De Haan 1976, Sinsabaugh et al. 1992). In the abovementioned investigations peroxidases were detected as contributors to 
microbial breakdown of humic substances. In addition to a degradative role, peroxidases are also involved in the polymerisation of aromatic compounds, e.g. humic substances (Saccomandi et al. 1998, Piccolo et al. 2000, Cozzolino \& Piccolo 2002), phenols and anilines (Dec \& Bollag 1994, Colosi et al. 2007).

The objective of the present study was to determine whether extracellular peroxidases occur in Lake Große Fuchskuhle (northern Germany), and if so, whether they are involved in degradation of humic substances. Lake Große Fuchskuhle was subdivided in 1989 into 4 compartments, which resulted in a divergence of physical and chemical parameters (Koschel 1995, Sachse et al. 2001, Burkert et al. 2004), microbial activities (Bittl \& Babenzien 1996, Casper et al. 2003, Burkert et al. 2003), abundance and structure of phytoplankton communities (Hehmann \& Krienitz 1996, Hehmann et al. 2001), and structure of the microbial food web (Šimek et al. 1998). These characteristics are also reflected in differences in the composition and concentration of dissolved organic carbon (DOC), with considerable divergence in concentrations of humic substances (Bittl 1999, Sachse et al. 2001). Due to the high concentration of humic substances, and due to the divergence in DOC quality, we proposed at the outset that extracellular peroxidase activity would differ between the compartments of Lake Große Fuchskuhle. To test this proposition, differences in extracellular peroxidase activity between the compartments of Lake Große Fuchskuhle and in the catchment area were analysed, and seasonal changes in peroxidase activity assessed. In addition, we measured changes in DOC over time.

\section{MATERIALS AND METHODS}

Study site. Lake Große Fuchskuhle is a naturally acidic lake situated $59 \mathrm{~m}$ above mean sea level in the Mecklenburg-Brandenburg Lake District in northeastern Germany (Fig. 1). The surface area of the lake is $15000 \mathrm{~m}^{2}$, the median depth is $3.3 \mathrm{~m}$ and its catchment area is $5000 \mathrm{~m}^{2}$. The lake is connected to a fen of LedoPinetum vegetation (Succow \& Jeschke 1986) on 2 sides, which is extensive in the southwest and less developed to the northeast. The lake has no inlet or outlet, but is fed by rain and groundwater.

In 1986 the lake was divided into 2 permanent compartments, which were again subdivided in 1989: southwest (SW), northwest (NW), northeast (NE) and southeast (SE) compartments (Kasprzak et al. 1988, Kasprzak 1993).

For the present study, 2 compartments that had developed very differently were selected: the SW compartment with an acidotrophic humic character and a high influx of allochthonous DOC $(\mathrm{pH}$ range:
4.69 to 5.03 between September 2000 and September 2001), and the NE compartment with a more eutrophic character (pH range: 5.79 to 6.79 between September 2000 and September 2001; Burkert et al. 2004). In order to study the influence of the catchment area on the microbial activity in the compartments, one experimental well (I/1) located in the fen adjacent to the SW compartment, and a second (III/1) located in the fen adjacent to the NE compartment were selected (Fig. 1).

Sampling and fixation. The investigation was done between June 2000 and September 2001 at approximately monthly intervals. Lake water from the 2 compartments was collected from a depth of $0.5 \mathrm{~m}$. Before sampling, 21 of water from well I/1 and from well III/1 were discarded, samples were collected with a boat pump after the wells had refilled with interstitial water. Measurements of extracellular enzyme activity were made within $2 \mathrm{~h}$ of sampling. Cooled subsamples for DOC analyses were analysed within $48 \mathrm{~h}$.

Extracellular peroxidases. The activity of extracellular peroxidases was measured in a microplate assay using the chromogen 2,2'-azino-di-(3-ethylbenzthiazoline-6-sulphonic acid) (ABTS) as substrate (Childs \& Bardsley 1975, Wolfenden \& Willson 1982, Heinzkill 1995). The rate of ABTS oxidation was measured at $405 \mathrm{~nm}\left(\varepsilon_{405}=3.68 \times 10^{4} \mathrm{M}^{-1} \mathrm{~cm}^{-1}\right)$ with a spectrophotometer (Rainbow Reader, Tecan). The collected water was filtered at a pressure of 100 mbar, or by gravity alone, through polycarbonate filters (pore size, $0.2 \mu \mathrm{m}$, diameter $25 \mathrm{~mm}$, Schleicher \& Schuell). The

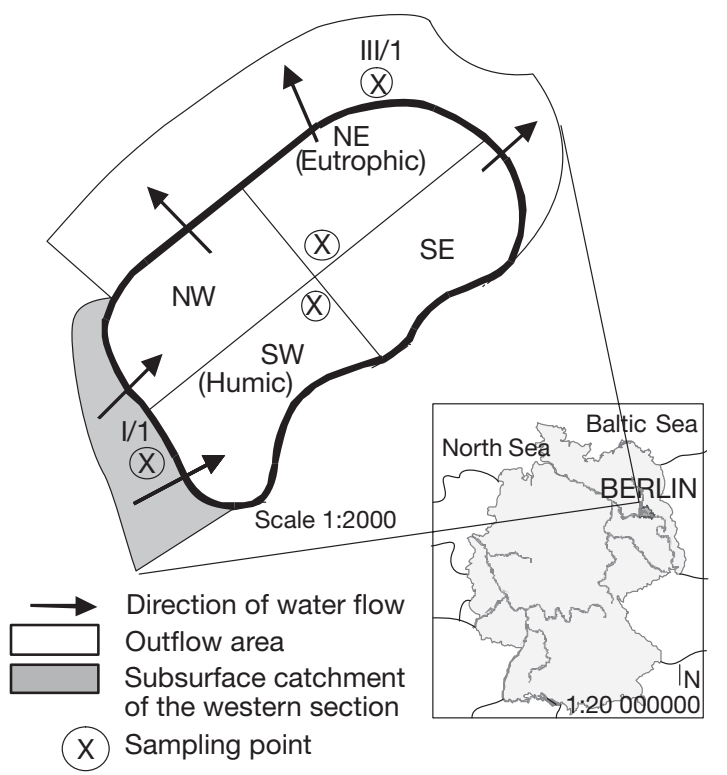

Fig. 1. Location of Lake Große Fuchskuhle in the Mecklenburg-Brandenburg Lake District in northeastern Germany $\left(53^{\circ} 10^{\prime} \mathrm{N}, 13^{\circ} 02^{\prime} \mathrm{E}\right)$, and the hydrogeology of the catchment area and the compartments. Modified after Sachse et al. (2001) 
assay mixture contained the prefiltered lake or well water $(240 \mu \mathrm{l}), 1.2 \mathrm{mM}$ ABTS $(30 \mu \mathrm{l})$ and $1.5 \mathrm{mM}$ hydrogen peroxide $(30 \mu \mathrm{l})$. The ABTS working solution was prepared in a buffer solution of $50 \mathrm{mM} \mathrm{Na} \mathrm{NPO}_{4}$ ( $\mathrm{pH}$ 5). The samples for measurements were incubated for $2 \mathrm{~h}$ in the dark at in situ temperature and at the $\mathrm{pH}$ of the source water. For the controls, $0.2 \mu \mathrm{m}$ autoclaved prefiltered lake water was used. The determinations of the $\mathrm{pH}$ optimum and the size fractions of water samples connected to the extracelluar peroxidase activity were done on 21 May 2001. The optimal pH of extracellular peroxidase was determined by adding appropriate buffers to the water samples: $0.1 \mathrm{M}$ phthalic acid for the $\mathrm{pH} 3$ to 6 and $0.1 \mathrm{M}$ borate buffer for the $\mathrm{pH} 7$ to 10 . In order to determine the size fractions of water samples associated with extracelluar peroxidase activity, a tangential-flow ultrafiltration system (Pro Vario-3, Filtron) was used to separate the lake water into 4 fractions: $0.2-1.2 \mu \mathrm{m}, 10 \mathrm{kDa}-0.2 \mu \mathrm{m}$, $1-10 \mathrm{kDa},<1 \mathrm{kDa}$. Measurements of the activity of extracellular peroxidases in different size fractions of the water samples were done as described above.

Carbon analyses. The quality and quantity of the DOC pools were analysed by liquid chromatography followed by organic carbon detection (LC-OCD) (Huber \& Frimmel 1991, Huber et al. 1994, Sachse et al. 2001). In this method, size-exclusion chromatography, using a stainless steel column $(250 \times 20 \mathrm{~mm})$ packed with TSK HW-50S resin (Toyopearl), and detectors for absorbance $(245 \mathrm{~nm})$ and DOC are combined. The DOC was UV oxidized in a cylindrical UV thin-film reactor (Gränzel) and $\mathrm{CO}_{2}$ was detected by infrared (IR) absorbance at $185 \mathrm{~nm}$. Phosphate buffer $\left(0.029 \mathrm{~mol} \mathrm{l}^{-1}, \mathrm{pH} 6.5\right)$ was used as the eluent. The flow

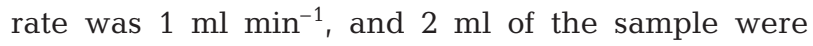
injected. Four different DOC fractions were distinguished and quantified: polysaccharides (PS), humic substances (HS), low molecular weight carboxylic acids (LMWA) belonging to the labile fraction of the carbon pool and others (proteins, peptides or amino acids) (Huber \& Frimmel 1991, Huber et al. 1994). In contrast to the UV-active HS fraction, the PS fraction was undetectable in the UV range. All 4 DOC fractions were identified by use of standards (humic and fulvic acid standards from the International Humic Substances Society, IHSS) and simple compounds of different origin. For molecular weight (MW) calibration, saccharides-raffinose $\left(\mathrm{MW}=594 \mathrm{~g} \mathrm{~mol}^{-1}\right.$, Merck), maltose $\left(\mathrm{MW}=360 \mathrm{~g} \mathrm{~mol}^{-1}\right.$, Merck) and glucose $\left(\mathrm{MW}=180 \mathrm{~g} \mathrm{~mol}^{-1}\right.$, Merck $)-$ methanol $(\mathrm{MW}=$ $32 \mathrm{~g} \mathrm{~mol}^{-1}$, Merck) - and polydextranes $(\mathrm{MW}=830$, 4400, 9900, 21400, $43500 \mathrm{~g} \mathrm{~mol}^{-1}$, Polymer Standards Service) were used. The calibration curve $(\lg M=$ $\left.-0.0983 t_{\mathrm{R}}+7.4027\right)$ was obtained by plotting the retention times $\left(t_{\mathrm{R}}\right)$ of the standards against the loga- rithms of their molecular weights (MW). The limits of quantification for the various fractions were $0.3 \mathrm{mg} \mathrm{l}^{-1}$ $\mathrm{C}$ for DOC, $0.02 \mathrm{mg} \mathrm{l}^{-1} \mathrm{C}$ for PS, $0.2 \mathrm{mg} \mathrm{l}^{-1} \mathrm{C}$ for $\mathrm{HS}$, $0.15 \mathrm{mg} \mathrm{l}^{-1} \mathrm{C}$ for LMWA and $0.1 \mathrm{mg} \mathrm{l}^{-1} \mathrm{C}$ for others.

Statistical analyses. All statistical tests were performed with the program SPSS 9.0. ANOVA (Post hoc test, Scheffe) was used to investigate significance differences in the measured parameters. Significance was given at $\mathrm{p}$-values $<0.05$.

\section{RESULTS}

\section{Extracellular peroxidase activity}

In the SW compartment, extracellular peroxidase activity was detected from June 2000 until June 2001 and in September 2001 (Fig. 2), but only from June 2000 until October 2000 and in May 2001 in the NE compartment (Fig. 2). Except for July 2000, the activity of extracellular peroxidases was significantly higher in the humic SW compartment ( 0.06 to $4.71 \mathrm{mmol}^{-1} \mathrm{~h}^{-1}$, mean $1.39 \mathrm{mmol} \mathrm{l}^{-1} \mathrm{~h}^{-1}$ ) than in the eutrophic NE compartment (0.16 to $1.36 \mathrm{mmol} \mathrm{l}^{-1} \mathrm{~h}^{-1}$, mean $0.73 \mathrm{mmol} \mathrm{l}^{-1} \mathrm{~h}^{-1}$ ).

The $\mathrm{pH}$ optimum of extracellular peroxidase activity was around pH 3 (Fig. 3). Below 10 kDa, no peroxidase activity was detected. We detected the highest peroxidase activity (mean $\pm \mathrm{SD}, 4.4 \pm 0.24 \mathrm{mmol} \mathrm{l}^{-1} \mathrm{~h}^{-1}$ ) in the size class $10 \mathrm{kDa}-0.2 \mu \mathrm{m}$, which implies that peroxidases were released into the water and persisted as dissolved free extracellular enzymes. The activity of peroxidases in the size class $0.2-1.2 \mu \mathrm{m}$ was $2.1 \pm$ $0.15 \mathrm{mmol} \mathrm{l}^{-1} \mathrm{~h}^{-1}$, which indicates that surface-bound

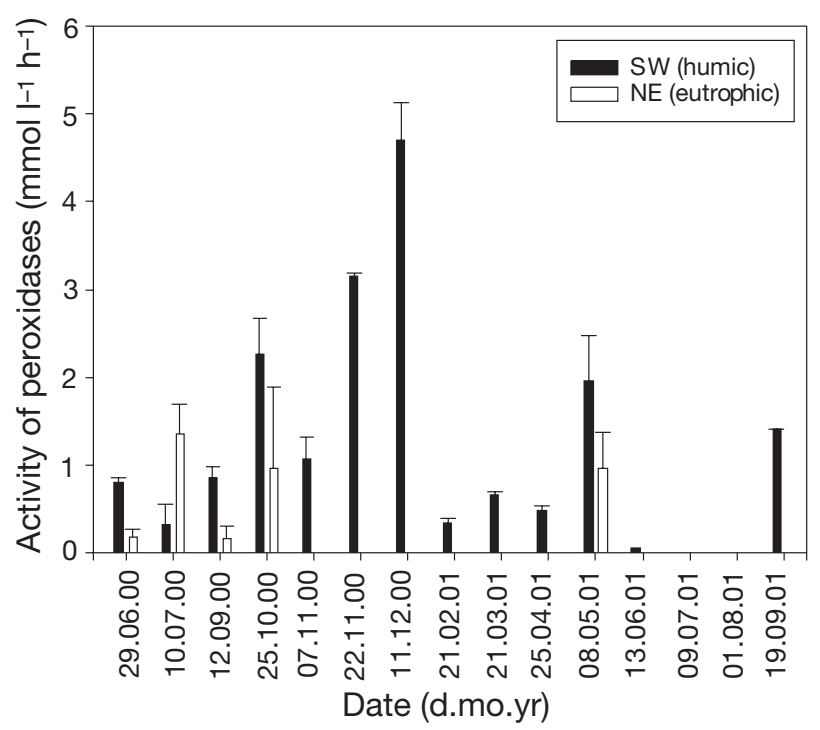

Fig. 2. Extracellular peroxidase activity in the humic SW and the eutrophic NE compartments of Lake Große Fuchskuhle. Means $\pm \mathrm{SE}, \mathrm{n}=3$ 


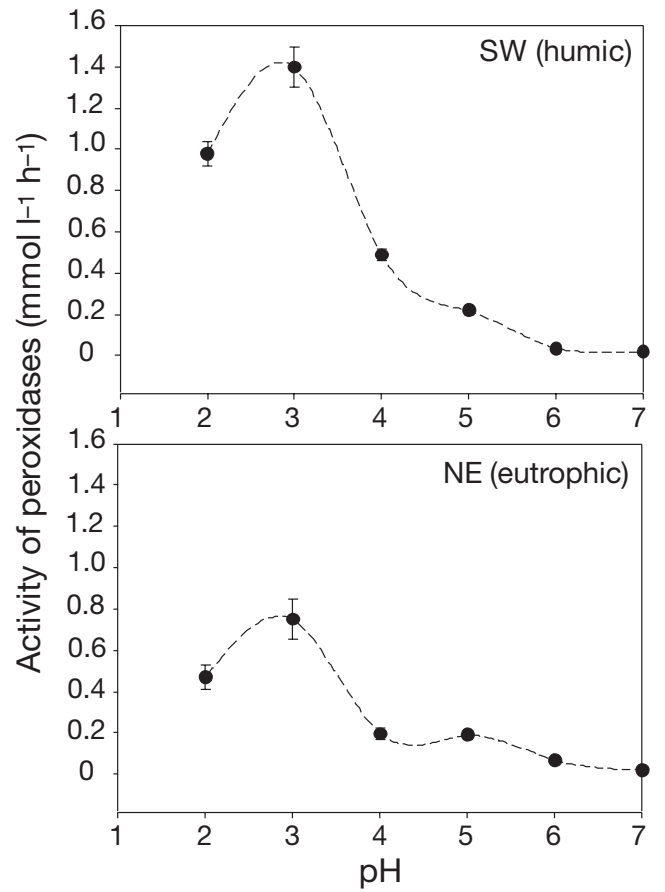

Fig. 3. pH optima of extracellular peroxidases in the humic SW and eutrophic NE compartments of Lake Große Fuchskuhle. Means $\pm \mathrm{SE}, \mathrm{n}=3$

enzymes were measured. In the catchment area, no peroxidase activity was detected due to the method used for enzyme activity determination (high concentrations of humic substances interfere with this method).

\section{DOC analyses}

DOC concentration in the humic SW compartment ranged from 12.0 to $16.2 \mathrm{mg} \mathrm{Cl}^{-1}$, and in the eutrophic NE compartment from 10.0 to $11.9 \mathrm{mg} \mathrm{C}^{-1}$ (Fig. 4). The HS fraction made up the largest proportion of DOC in all samples (Fig. 4). In the SW compartment, the concentration of $\mathrm{HS}$ ranged from 8.4 to $12.5 \mathrm{mg} \mathrm{C}$ $\mathrm{l}^{-1}$ (68 to $82 \%$ of the DOC), and in the NE compartment from 4.9 to $6.3 \mathrm{mg} \mathrm{Cl}^{-1}$ ( 47 to $55 \%$ of the DOC). The concentration of PS ranged from 0.7 to $2.2 \mathrm{mg} \mathrm{Cl}^{-1}$ (5.3 to $13.5 \%$ of the DOC) in the SW compartment, and from 2.4 to $4.4 \mathrm{mg} \mathrm{C}^{-1}$ (22.7 to $42.1 \%$ of the DOC) in the NE compartment. The concentrations of LMWA were negligible in both compartments. In the SW compartment, the concentration of the fraction 'others' (e.g.

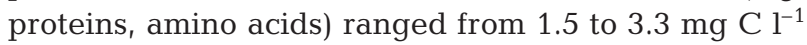
( 9.9 to $23.5 \%$ of the DOC) and in the NE compartment from 1.1 to $3.6 \mathrm{mg} \mathrm{Cl}^{-1}$ (10.6 to $32.4 \%$ of the DOC). The DOC concentration ranged from 56.3 to $64.2 \mathrm{mg} \mathrm{C} \mathrm{l}^{-1}$ in well $\mathrm{I} / 1$, and from 24.6 to $27.6 \mathrm{mg} \mathrm{C} \mathrm{^{-1 }}$ in well III/1 (Fig. 5). High concentrations of HS were detected in

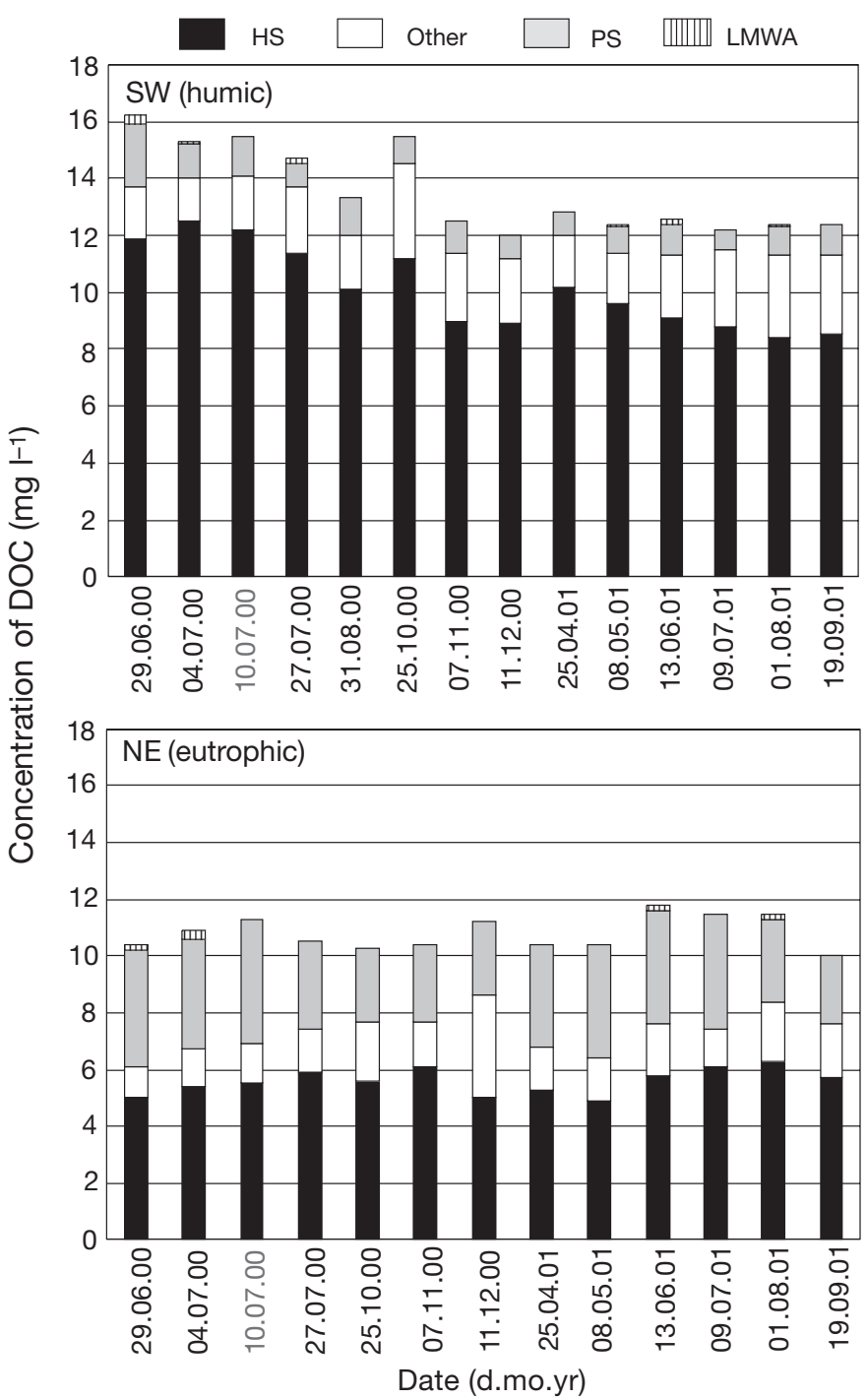

Fig. 4. Concentration and composition of DOC in the humic SW and eutrophic NE compartments of Lake Große Fuchskuhle from June 2000 through September 2001. HS: humic substances; Other: proteins, peptides or amino acids; PS: polysaccharides; LMWA: low molecular weight carboxylic acids. Data are means, $\mathrm{n}=3$. 10.07.00: only tendencies shown for these data

wells I/1 and III/1 (50.5 to 58.4 and 17.4 to $22.4 \mathrm{mg} \mathrm{C}$ $\mathrm{I}^{-1}$, respectively). The concentration of LMWA and the PS were negligible (Fig. 5). In well I/1, the concentration of the fraction 'others' ranged from 5.5 to $10.9 \mathrm{mg} \mathrm{Cl}^{-1}$ and from 4.3 to $6.5 \mathrm{mg} \mathrm{Cl}^{-1}$, in well III/1.

\section{DISCUSSION}

In Lake Große Fuchskuhle, there were differences in DOC composition between the 4 compartments (Fig. 4). In the SW compartment, humic substances 


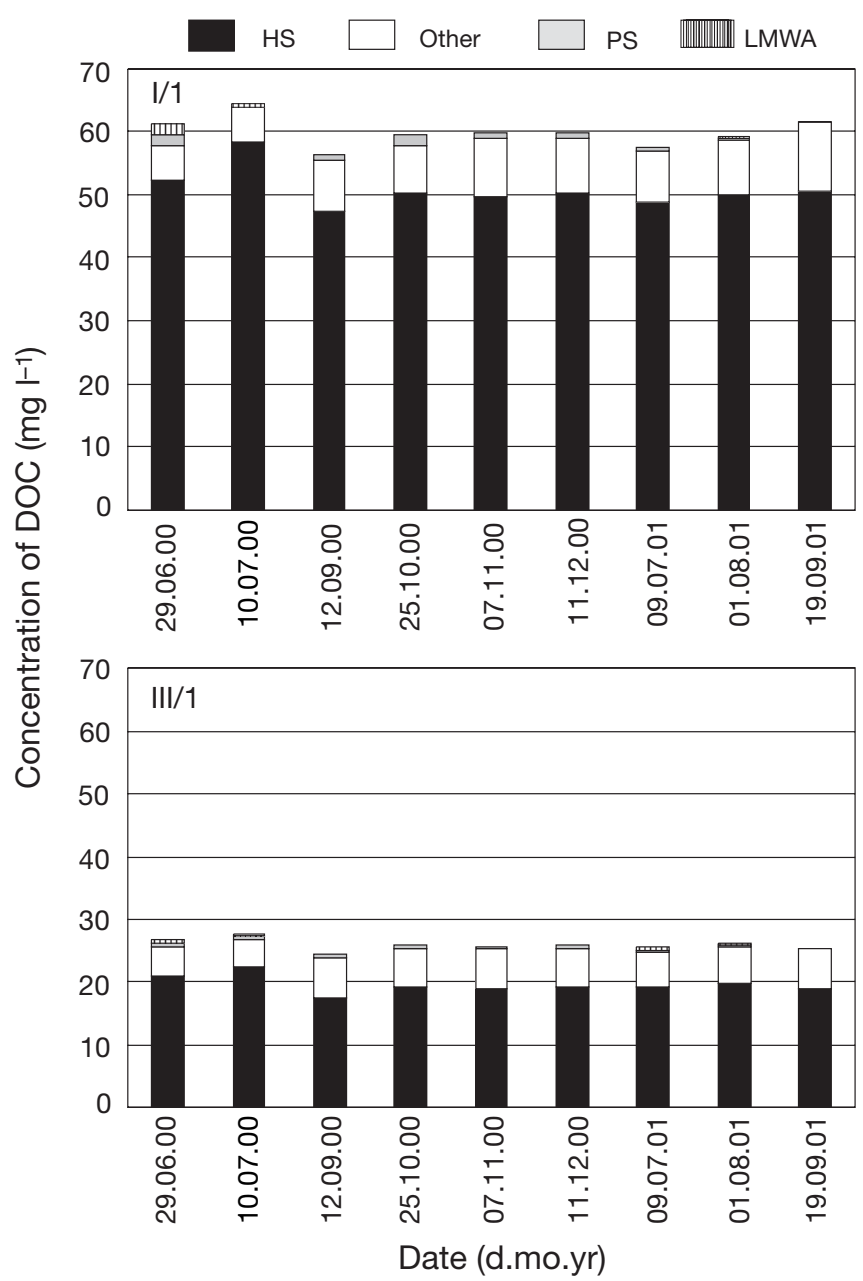

Fig. 5. Concentration and composition of the DOC in wells I/1 and III/1 of the catchment area of Lake Große Fuchskuhle from June 2000 through September 2001. HS: humic substances; Other: proteins, peptides or amino acids; PS: polysaccharides; LMWA: low molecular weight carboxylic acids. Data are means, $\mathrm{n}=3$

were in higher concentrations and polysaccharides in lower concentrations than in the NE compartment, which is in good agreement with earlier studies (Sachse et al. 2001, Burkert et al. 2004). During our study period, the portion of humic substances of the DOC were on average $74 \%$ in the SW and $51 \%$ in the NE compartments. From February to August 1998, the average humic acid fraction comprised $58 \%$ in the SW and $33 \%$ in the NE compartments of the DOC (Sachse et al. 2001). In 2004 samples of the SW compartment, this fraction increased to $80 \%$ (E. Zwirnmann unpubl. data). However, there were not only differences in the quality of DOC over time, there was also an increase in DOC concentration (Hehmann et al. 2001, Burkert 2006) These observations are concordant with reports of increased DOC concentrations in waters draining through peat (Robson \& Neal 1996) and in streams (Reynolds et al. 1997). In the catchment area (well I/1) adjacent to the humic SW compartment, there was a high concentration of humic substances (50.5 to $58.4 \mathrm{mg} \mathrm{C}^{-1}$ ) (Fig. 5). A portion of these humic substances may enter the lake, as shown in a previous study (Burkert et al. 2004). This indicates that the hydrology in the catchment area was and likely will continue to be responsible for changes in the quality and quantity of the DOC pool that in turn influence the diversity and physiology of aquatic organisms. Organisms that are able to attack humic substances might be favoured by these conditions.

High molecular weight compounds such as humic substances become available to bacteria after they are broken down by the action of extracellular enzymes that are located outside the cytoplasmic membrane (exoenzymes). These enzymes are dissolved in water and/or adsorbed to particles (Priest 1984). In order to avoid cell disruption and release of intracellular and surface bond peroxidases, the samples were prepared by passing them through $0.2 \mu \mathrm{m}$ pore size polycarbonate filters under a low filtration pressure of 100 mbar or using gravity only. This procedure minimised potential cell damage.

During the study period, there was a higher activity of extracellular peroxidases in the humic SW compartment than in the eutrophic NE compartment (Fig. 2). No correlation was found between peroxidase activity and concentration of humic substances; this lack of correlation may be due to the heterogeneity and chemical complexity of these high molecular weight compounds (data not shown). A positive correlation between extracellular peroxidase activity and aromatic carbon uptake (using a labelled hydroxybenzoic acid) has been documented for a humic boreal lake (Münster et al. 1999). Suitable model compounds of humic substances would help verify enzymatic degradation processes, but there are few high molecular weight compounds available. In addition, we are still lacking a comparable analytical system for aromatic carbons.

In contrast to the eutrophic NE compartment, the more acidic conditions in the humic SW compartment favoured the activity of extracellular peroxidases, which had a pH optimum at pH 3 (Fig. 3). This is similar to the $\mathrm{pH}$ optima for related enzymes (extracellular lignin peroxidases) of the fungi Phanerochaete chrysosporium ( $\mathrm{pH}$ 2.5) (Tien et al. 1986, Gold et al. 1989) and Vaccinium myrtillus ( $\mathrm{pH}$ 3.4) (Melo et al. 1995). Extracellular peroxidases have molecular masses of approximately $40 \mathrm{kDa}$ (Hatakka 2001), a size comparable to our measurements (highest activity in the size class $10 \mathrm{kDa}-0.2 \mu \mathrm{m})$. The activity of extracellular peroxidases in the humic SW and the eutrophic NE compartments ranged from 0.06 to 4.71 and 0.16 to 
$1.36 \mathrm{mmol} \mathrm{l}^{-1} \mathrm{~h}^{-1}$, respectively. The activities of extracellular lignin peroxidase range from 0.001 to $0.5 \mu \mathrm{mol}$ $\mathrm{l}^{-1} \mathrm{~h}^{-1}$ in a river system (Sinsabaugh \& Linkins 1990)

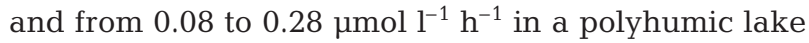
(Münster et al. 1998), values that are much lower than the activities of extracellular peroxidases in Lake Große Fuchskuhle. In these studies other substrates, namely veratryl alcohol (VeraOH) and dihydroxyphenylalanine (L-DOPA) were used, which may be one reason for these remarkable differences in the detection of extracellular peroxidase activity. In our study, the activity of extracellular peroxidases was assayed by oxidizing ABTS. This chromogen was chosen because of its specificity to extracellular peroxidase activity (Heinzkill 1995, Mercer et al. 1996), its ease of handling, its well defined reactivity and chemical properties (Becker 1974, Childs \& Bardsley 1975, Wolfenden \& Willson 1982).

In addition to numerous species of basidiomycetes (especially white-rot fungi), actinobacterial strains from terrestrial habitats are able to produce extracellular peroxidases (Ramachandra et al. 1987, 1988, Godden et al. 1992, Mercer et al. 1996). For example, the Actinobacterium Streptomyces viridosporus T7A produces a variety of extracellular enzymes such as peroxidases that play a role in lignin degradation (Yee et al. 1996). In Lake Große Fuchskuhle, the Actinobacteria group was an important component of the microbial community in the SW and NE compartments, comprising on average 23 and $20 \%$, respectively, of all cells (Burkert et al. 2003). These aquatic Actinobacteria may be able to produce extracellular peroxidases in ways similar to their relatives in the soil. Support for this proposition may be found in the concurrence between high abundances of Actinobacteria and elevated extracellular peroxidase activity in November and December 2000 in the humic SW compartment (Burkert et al. 2003) (Fig. 2). During these months, the abundance of Actinobacteria was lower in the eutrophic NE compartment and no extracellular peroxidase activity was detected. It is possible that the more neutral $\mathrm{pH}$ in the NE compartment does not favour extracellular peroxidase activity. There were also differences in phylo-genetic diversity and seasonal abundance dynamics of freshwater Actinobacteria between the eutrophic NE and humic SW compartments (Allgaier \& Grossart 2006). Further investigations using molecular genetic techniques based on PCR amplification of genes encoding peroxidases or oxygenases would be appropriate for detection and quantification of aromatic catabolic pathways and the organisms in which these metabolic processes occur (Broda et al. 1995, Chambers et al. 1999, Baldwin et al. 2003, Brzostowicz et al. 2003)

In summary, the high concentration of humic substances, the high extracellular peroxidase activity and the high abundance of Actinobacteria as potential producers of these enzymes in the SW compartment of Lake Große Fuchskuhle may be an indication of the utilisation of humic substances by this bacterial group.

Acknowledgements. We express our gratitude to R. Koschel, H. P. Grossart and E. Allers for valuable comments on the manuscript and to S. Poynton for linguistic revision. We thank the anonymous reviewers for their valuable comments, which helped to improve the manuscript. The authors thank the Deutsche Forschungsgemeinschaft for supporting this study (DFG-project Ba 1288/5-2).

\section{LITERATURE CITED}

Allgaier M, Grossart H (2006) Diversity and seasonal dynamics of Actinobacteria populations in four lakes in northeastern Germany. Appl Environ Microbiol 72:3489-3497

Baldwin BR, Nakatsu CH, Nies L (2003) Detection and enumeration of aromatic oxygenase genes by multiplex and real-time PCR. Appl Environ Microbiol 69:3350-3358

Becker R (1974) Die Bestimmung des Wasserstoffperoxids und der Peroxidase mit 2,2'-Azino-di-[3-äthyl-benzthiazolin-sulfonsäure-(6)]. PhD dissertation, Justus LiebigUniversity, Gießen

Bittl T (1999) Bakterieller Stoffumsatz und mikrobielles Nahrungsnetz im Pelagial eines Moorsees (Experimentalgewässer Große Fuchskuhle). PhD dissertation, Humboldt University, Berlin

Bittl T, Babenzien D (1996) Microbial activities in an artificially divided acidic lake. Arch Hydrobiol Spec Iss Adv Limnol 48:113-121

- Broda P, Birch P, Brooks P, Sims P (1995) PCR-mediated analysis of lignocellulolytic gene transcription by Phanerochaete chrysosporium: substrate-dependent differential expression within gene families. Appl Environ Microbiol 61:2358-2364

Brzostowicz PC, Walters DM, Thomas SM, Nagarajan V, Rouviere PE (2003) mRNA differential display in a microbial enrichment culture: simultaneous identification of three cyclohexanone monooxygenases from three species. Appl Environ Microbiol 69:334-342

Burkert U (2006) Mikrobielle Aktivität in dem huminstoffreichen Moorsee Große Fuchskuhle. PhD dissertation, University Bremen

Burkert U, Warnecke F, Babenzien D, Pernthaler J (2003) Members of a readily enriched $\beta$-proteobacterial clade are common in surface waters of a humic lake. Appl Environ Microbiol 69:6550-6559

Burkert U, Ginzel G, Babenzien D, Koschel R (2004) The hydrogeology of a catchment area and an artificially divided dystrophic lake-consequences for the limnology of Lake Fuchskuhle. Biogeochemistry 71:225-246

Casper P, Chan O, Furtado A, Adams D (2003) Methane in an acidic bog lake: the influence of peat in the catchment on the biogeochemistry of methane. Aquat Sci 65:36-46

Chambers S, Burke R, Brooks P, Cairney J (1999) Molecular and biochemical evidence for manganese-dependent peroxidase activity in Tylospora fibrillosa. Mycol Res 103: 1098-1102

Childs RE, Bardsley WG (1975) The steady-state kinetics of peroxidase with 2,2'-azino-di-(3-ethyl-benzthiazoline-6sulphonic acid) as chromogen. Biochem J 145:93-103

Colosi LM, Burlingame DJ, Huang Q, Weber WJ Jr (2007) 
Peroxidase-mediated removal of a polychlorinated biphenyl using natural organic matter as the sole cosubstrate. Environ Sci Technol 41:891-896

$>$ Cozzolino A, Piccolo A (2002) Polymerization of dissolved humic substances catalyzed by peroxidase. Effects of $\mathrm{pH}$ and humic composition. Org Geochem 33:281-294

$>$ Dec J, Bollag J (1994) Dehalogenation of chlorinated phenols by oxidative coupling. Environ Sci Technol 28:484-490

$>$ De Haan H (1976) Evidence for the induction of catechol-1,2oxygenase by fulvic acid. Plant Soil 45:129-136

Godden B, Ball A, Helvenstein P, McCarthy A, Penninckx M (1992) Towards elucidation of the lignin degradation pathway in actinomycetes. J Gen Microbiol 138:2441-2448

Gold M, Wariishi H, Valli K (1989) Extracellular peroxidases involved in lignin degradation by the white rot basidiomycete Phanerochaete chrysosporium. ACS Symp Ser 389:127-140

Hatakka A (2001) Biodegradation of lignin. In: Hofrichter M, Steinbuechel A (eds) Biopolymers, Vol 1. Lignin, humic substances and coal. Wiley-VCH, Weinheim, p 129-180

Hehmann A, Krienitz L (1996) The succession and vertical distribution of phytoplankton of the experimental divided naturally acidic lake 'Große Fuchskuhle' (Brandenburg, Germany). Limnologica 26:301-309

> Hehmann A, Krienitz L, Koschel R (2001) Long-term phytoplankton changes in an artificially divided, top-down manipulated humic lake. Hydrobiologia 448:83-96

Heinzkill M (1995) Isolierung und Charakterisierung von Laccasen und Peroxidasen aus Basidiomyceten der Ordnung Agaricales. PhD dissertation, University of Kaiserslautern

Huber S, Frimmel F (1991) Flow injection analysis of organic and inorganic carbon in the low-ppb range. Anal Chem 63:2122-2130

Huber S, Balz A, Frimmel F (1994) Characterization and quantification of marine dissolved organic carbon with a direct chromatographic method. Environ Sci Technol 28: 1194-1197

Kasprzak P (1993) The use of an artificially divided bog lake in food web studies. Verh Internat Ver Limnol 25:652-656

Kasprzak P, Koschel R, Steiner U, Metzdorf K (1988) 'Enclosure' experiments in food-web manipulation: first stepdividing the experimental lake. Limnologica 19:161-165

Koschel R (1995) Manipulation of whole lake ecosystems and long term limnological observations of the BrandenburgMecklenburg lake district. Int Rev Gesamten Hydrobiol 80:507-518

Melo N, Cabral J, Pedro Fevereiro M (1995) Extracellular peroxidase from cell suspension cultures of Vaccinium myrtillus. Purification and characterization of two cationic enzymes. Plant Sci 106:177-184

Mercer DK, Iqbal M, Miller P, McCarthy AJ (1996) Screening Actinomycetes for extracellular peroxidase activity. Appl Environ Microbiol 62:2186-2190

Münster U, Heikkinen E, Salonen K, De Haan H (1998) Tracing of peroxidase activity in humic lake water. Acta Hydrochim Hydrobiol 26:158-166

Münster U, Heikkinen E, Likolammi M, Järvinen M, Salonen K, De Haan H (1999) Utilisation of polymeric and monomeric aromatic and amino acid carbon in a humic boreal

Editorial responsibility: Karel Šmek, České Budějovice, Czech Republic forest lake. Arch Hydrobiol Spec Iss Adv Limnol 54: 105-134

Petersen J, Tams J, Vind J, Svensson A, Dalboge H, Welinder K, Larsen S (1993) Crystallization and x-ray diffraction analysis of recombinant Coprinus cinereus peroxidase. J Mol Biochem 232:989-991

Piccolo A, Cozzolino A, Conte P, Spaccini R (2000) Polymerization of humic substances by an enzyme-catalyzed oxidative coupling. Naturwissenschaften 87:391-394

Priest F (1984) Extracellular enzymes. Van Nostand Reinhold, Wokingham

Ramachandra M, Crawford D, Hertel G (1987) Extracellular enzyme activities during lignocellulose degradation by Streptomyces spp.: a comparative study of wild type and genetically manipulated strains. Appl Environ Microbiol 53:2754-2760

Ramachandra M, Crawford D, Hertel G (1988) Characterization of an extracellular lignin peroxidase of the lignocellulolytic actinomycete Streptomyces viridosporus. Appl Environ Microbiol 54:3057-3063

Reynolds B, Renshaw M, Sparks T, Crane S, Hughes S, Brittain S, Kennedy V (1997) Trends and seasonality in stream water chemistry in two moorland catchments of the Upper River Wye, Plynlimon. Hydrol Earth Syst Sci 1:571-581

Robson A, Neal C (1996) Water quality trends at an upland site in Wales. Hydrol Process 10:183-203

Saccomandi F, Conte P, Piccolo A (1998) Use of oxidase enzyme to increase polymerization of soil organic matter. Fresenius Environ Bull 7:537-543

Sachse A, Babenzien D, Ginzel G, Gelbrecht J, Steinberg C (2001) Characterization of dissolved organic carbon (DOC) in a dystrophic lake and an adjacent fen. Biogeochemistry 54:279-296

Šimek K, Babenzien D, Bittl T, Koschel R, Macek M, Nedoma J, Vrba J (1998) Microbial food webs in an artificially divided acidic bog lake. Int Rev Hydrobiol 83:3-18

Sinsabaugh R, Linkins A (1990) Enzymic and chemical analysis of particulate organic matter from a boreal river. Freshw Biol 23:301-309

Sinsabaugh R, Weiland T, Linkins A (1992) Enzymatic and molecular analysis of microbial communities associated with lotic particulate organic matter. Freshw Biol 28:393-404

Succow M, Jeschke L (1986) Moore in der Landschaft. Urania Verlag, Leipzig

Tien M, Kirk TK, Bull C, Fee JA (1986) Steady-state and transient-state kinetic studies on the oxidation of 3,4-dimethoxybenzyl alcohol catalyzed by the ligninase of Phanerocheate chrysosporium Burd. J Biol Chem 261:1687-1693

Tuomela M, Vikman M, Hatakka A, Itävaara M (2000) Biodegradation of lignin in a compost environment: a review. Bioresour Technol 72:169-183

Wolfenden B, Willson R (1982) Radical cations as reference chromogens in kinetic studies of one electron transfer reactions: pulse radiolysis studies of 2,2'-azinobis-(3ethyl-benzthiazoline-6-sulphonate). J Chem Soc Perkin Trans II 1982:805-812

Yee D, Jahng D, Wood T (1996) Enhanced expression and hydrogen peroxide dependence of lignin peroxidase from Streptomyces viridosporus T7A. Biotechnol Prog 12:40-46

Submitted: August 30, 2007; Accepted: February 16, 2008 Proofs received from author(s): April 14, 2008 